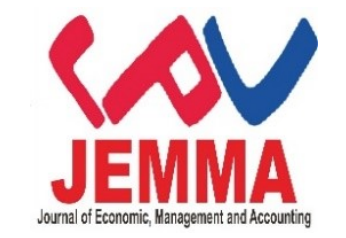

JEMMA | JURNAL OF ECONOMIC, MANAGEMENT, AND ACCOUNTING

Fakultas Ekonomi Universitas Andi Djemma Jl. Puang H. Daud No 4 Kota Palopo

\title{
Mengungkap Nilai-Nilai Siri’ Na Pesse Kepemimpinan Pada BM Residence Hotel: Studi Etnometodologi Di Kota Palopo
}

Penulis
Khaerana $^{\mathbf{1}}$
Dosen Program Studi Manajemen
Universitas Andi Djemma Palopo
Email: khaerana.itowotu@gmail.com
Muh. Andi Zam ${ }^{2}$
Dosen Program Studi Manajemen
Universitas Andi Djemma Palopo
Email: muhandri@gmail.com

\author{
Info Artikel \\ p-ISSN : 2615-1871 \\ e-ISSN : 2615-5850 \\ Volume 3 Nomor 1, Maret 2020 \\ DOI: \\ http://dx.doi.org/10.35914/jemma.v3i1.326 \\ Article History: \\ Received, 4 Februari 2020 \\ Revised, 16 Februari 2020 \\ Accepted, 16 Maret 2020
}

\begin{abstract}
ABSTRAK
Tujuan penelitian ini adalah untuk mengungkap kepemimpinan berbasis Siri' Na Pesse pada BM Residence Hotel di Kota Palopo. Dalam mengungkap nilai-nilai siri'na pesse kepemimpinan maka dilakukan wawancara serta dokumentasi dari pimpinan perusahaan yang bersangkutan. Penelitian ini menggunakan dasar teori menajemen sumber daya manusia mengenai analisis kepemimpinan, alat yang digunakan dalam penelitian ini yaitu penelitian kualitatif dengan paradigma interpretif dan pendekatan etnometodologi. Berdasarkan hasil penelitian diketahui bahwa nilai-nilai siri'na pesse dilihat dari (1) wujud nilai tongeng pada kepemimpinan BM Residence Hotel adalah patuh pada aturan yang berlaku dan mampu mempertanggungjawabkannya. (2) wujud nilai lempu' pada kepemimpinan BM Residence Hotel yaitu memiliki sifat jujur yaitu apa yang dikatakan atau disepakati seyogyanya dilaksanakan dalam bentuk tindakan; (3) wujud nilai getteng pada kepemimpinan BM Residence Hotel yaitu tegas dengan penuh keteguhan hati; (4) wujud adele' pada kepemimpinan BM Residence Hotel tidak membedakan antara sesama karyawan dan menciptakan harmonisasi dalam perusahaan; (5) wujud nilai sipakatau pada kepemimpinan BM Residence Hotel adalah saling menghargai dan menghormati sesama karyawan dan pimpinan.
\end{abstract}

Kata Kunci: Nilai-nilai Siri' Na Pesse dan Kepemimpinan.

\section{PENDAHULUAN}

Perkembangan dunia bisnis yang pesat khususnya di sektor pariwisata dewasa ini menuntut setiap organisasi dan perusahaan untuk bersikap lebih responsif agar sanggup bertahan dan terus berkembang dalam menghadapi persaingan. Usaha perhotelan saat ini tidak hanya sekedar menyediakan fasilitas penginapan, makanan, dan minuman saja, tetapi sudah berkembang ke 
pemenuhan kebutuhan lainnya seperti terapi, hiburan, olahraga, dan rekreasi. Perkembangan hotel ini dipengaruhi oleh pesatnya perkembangan wisata, kunjungan bisnis dan beberapa alasan lainnya di suatu daerah. Perkembangan ini menuntut setiap hotel untuk bersikap lebih responsif agar sanggup bertahan dan terus berkembang. Perusahaan harus mempersiapkan strategi yang kuat agar dapat mempertahankan posisi kompetitif ditengah persaingan, maka dari itu, organisasi memerlukan pemimpin reformis yang mampu menjadi motor penggerak yang mendorong perubahan organisasi. Pemimpin yang efektif adalah pemimpin yang mengakui kekuatankekuatan penting yang terkandung dalam individu. Begitu pentingnya peran kepemimpinan dalam sebuah organisasi menjadi fokus yang menarik perhatian para peneliti bidang perilaku keorganisasian. Kualitas dari pemimpin sering kali dianggap sebagai faktor terpenting yang menentukan keberhasilan atau kegagalan organisasi.

Kepemimpinan adalah kemampuan untuk mempengaruhi orang lain untuk mencapai tujuan dengan antusias (David, 1985) dalam (Ruvendi, 2005). Menurut Rivai (2004) dalam Mariam (2009), kepemimpinan juga dikatakan sebagai proses mengarahkan dan mempengaruhi aktivitas-aktivitas yang ada hubungannya dengan pekerjaan para anggota kelompok. Tiga implikasi penting yang terkandung dalam hal ini yaitu : (1) Kepemimpinan itu melibatkan orang lain baik itu bawahan maupun pengikut. (2) Kepeminpinan melibatkan pendistribusian kekuasaan antara pemimpin dan anggota kelompok secara seimbang, karena anggota kelompok bukanlah tanpa daya. (3) Adanya kemampuan untuk menggunakan bentuk kekuasaan yang berbeda untuk mempengaruhi tingkah laku pengikutnya melalui berbagai cara.

Sementara dalam konsep kepemimpinan di Sulawesi Selatan, khususnya Bugis - Makssar lebih menekankan pada nilai-nilai kearifan lokal yaitu kepemimpinan Siri' na Pesse. Menurut Hamid, (2005) dalam Tenrigau dan Damayanti (2015) Pesse na siri' merupakan dua kosa kata yang membentuk istilah yang sangat dikenal luas masyarakat Sulawesi Selatan sejak dahulu. Pesse berarti toleransi kebatinan dan siri' merupakan malu. Istilah tersebut merupakan dua kosa kata yang mewakili sikap moral yang menjaga stabilitas dan berdimensi harmonisasi agar tatanan sosial berjalan secara dinamis. Abdullah (2003:37) dan Mattulada (2005:63) mengartikan siri' sebagai etos kerja atau harga diri (dignity), keteguhan hati (Mattulada, 2005:69-70), pendorong pembangunan (Lopa, 2005:93), dan iman (Al Gazali dalam Farid, 2005:28). Sementara Hamka dalam Tenrigau (2015) mengartikan sebagai menjaga harga diri dan sariat. Menurut Rahman (2002:67) dalam Tenrigau (2015) Secara fungsional, siri' na pesse tidak berdiri sendiri melainkan dibangun dari nilai-nilai tradisional yang dipraktekkan selama ini oleh masyarakat pendukungnya, meliputi tongeng (kebenaran), getteng (ketegasan), lempu' (kejujuran), dan adele' (keadilan). Adapun nilai tambahan, yaitu sipakatau (saling menghormati). Dengan demikian, antara siri' dan pessé harus tetap ada keseimbangan dalam memimpin sebuah perusahaan atau organisasi.

BM Recident Hotel merupakan salah satu hotel yang terletak di jalan Anggrek, Palopo. Perkembangan hotel di Palopo menimbulkan persaingan diantara hotel-hotel yang berada baru di daerah tersebut. Dengan banyaknya hotel di Palopo maka persaingan usaha perhotelan di Palopo 
menjadi semakin ketat. Hal ini memacu BM Residence Hotel untuk tetap bertahan dan mampu bersaing dengan para kompetitornya. Tidak bisa dipungkiri lagi bahwa kepemimpinan merupakan hal yang sangat berharga sehingga perlu diperhatikan agar organisasi dapat bertahan dan bersaing dengan para pesaing.

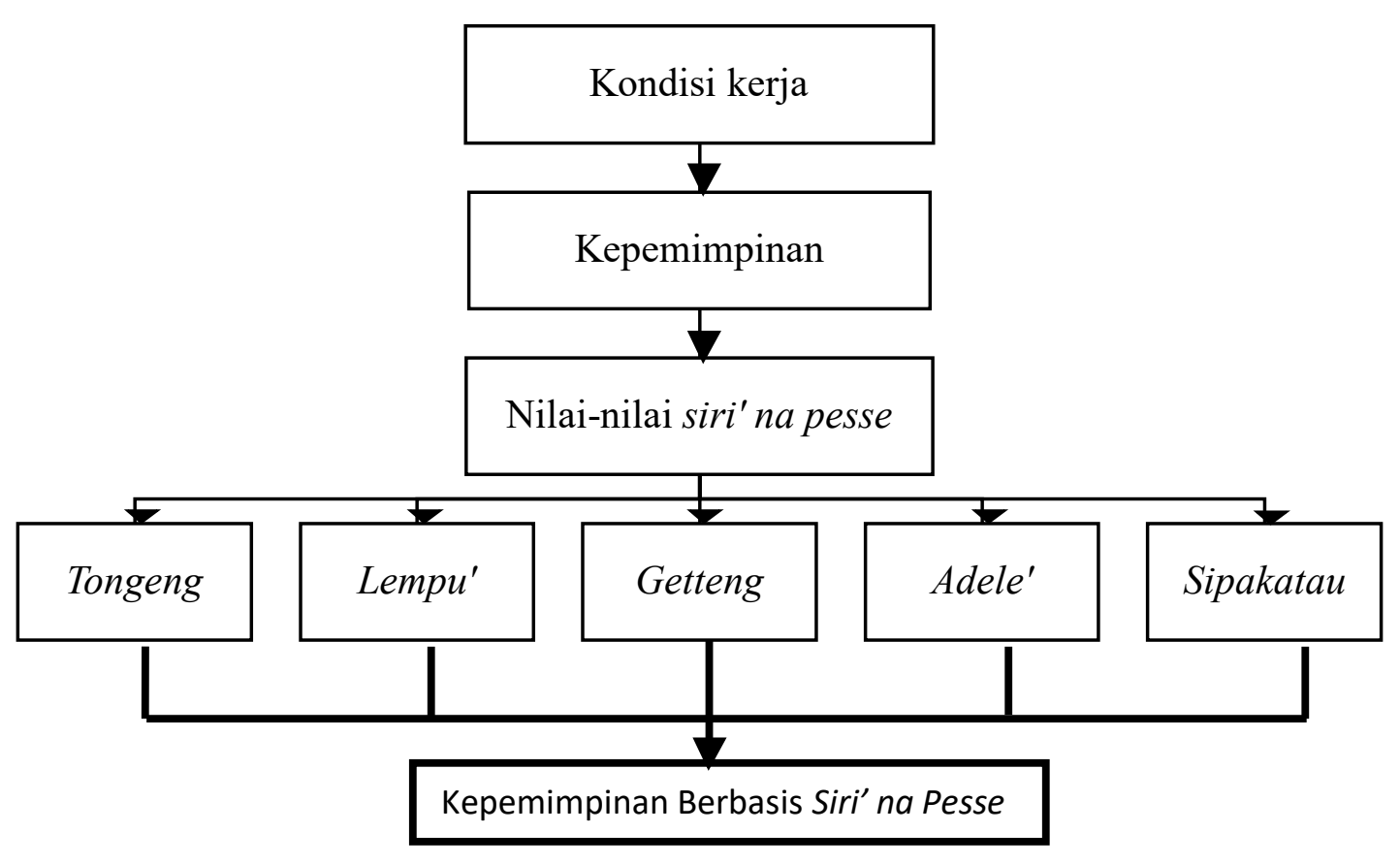

Gambar 2: Kerangka pikir

\section{METODE PENELITIAN}

Penelitian ini dilaksanakan di BM Residence Hotel Palopo. Penelitian ini menggunakan Jenis data kualitatif. Sementara Sumber data terbagi menjadi dua yaitu data primer dan data sekunder. Data primer merupakan data yang diperoleh langsung dari sumbernya tanpa diolah terlebih dahulu, meliputi hasil wawancara dan observasi lapangan. Sumber data yang digunakan dalam penelitian ini adalah data primer dimana peneliti secara langsung melakukan penelitian pada perusahaan yang menjadi sasaran penelitian yaitu BM Residence Hotel Palopo. Penelitian ini menggunakan paradigma Interpretif dengan menggunakan metode etnometodologi. Paradigma interpretif merupakan sebuah sistem sosial yang memaknai perilaku secara detail, melihat fenomena, dan menggali pengalaman dari objek penelitian. Sementara itu, pendekatan yang relevan dengan penelitian ini adalah Etnometodologi. Etnometodologi adalah kajian akal sehat, yakni kajian dari observasi penciptaan yang digunakan terus-menerus dalam interaksi sosial dengan lingkungan yang sewajarnya atau kegiatan yang dilaksanakan orang perorang secara rutin tiap hari.

Peneliti dapat memahami aktivitas sehari-hari yang dilakukan oleh individu dalam suatu komunitas, yaitu pemimpin hotel. Etnometodologi berupaya mengungkapkan aturan tak tertulis 
yang diikuti oleh anggota komunitas tanpa disadari secara eksplisit. Dengan mempelajari interaksi sosial yang terbentuk dalam suatu komunitas, peneliti berusaha mengidentifikasikan nilai-nilai siri' na pesse yang terbentuk dalam komunitas tersebut dan bagaimana pemimpin menerapkan nilai-nilai siri' na pesse tersebut, peneliti juga menganalisis pengalamanpengalaman informan di lapangan.

\section{HASIL DAN PEMBAHASAN}

\section{NILAI-NILAI KEPEMIMPINAN BM RESIDENCE HOTEL}

\section{Wujud Nilai Tongeng: Antara Aturan dan Tanggung Jawab}

Kepemimpinan pada BM Resideace Hotel Palopo tidak terlepas dari nilai tongeng. Nilai ini merupakan prinsip yang mengedepankan kebenaran yang berlandaskan pada aturan yang berlaku. Menegakkan tongeng berarti berpegang pada aturan dan kemudian mempertanggungjawabkan.

Kepemimpinan yang dijalankan pada BM Residance Hotel Palopo mengacu pada nilai tongeng yang diarahkan pada upaya untuk mencapai tujuan atau cita-cita yang telah ditetapkan. Pencapaian tujuan tersebut didasarkan pada aturan-aturan yang berlaku dalam perusahaan maupun yang mengikat secara eksternal kemudian dipertanggungjawabkan. Nilai tongeng yang dikedepankan dalam memimpin di BM Residance Hotel Palopo dimaknai sebagai sebuah kebijakan, prosedur, dan aturan. Wujud dari tongeng di antaranya adalah kedisiplinan masuk kantor. Aturan yang mengikat tersebut bahwa setiap karyawan masuk kantor baik pada waktu pagi maupun saat pergantian harus berdasarkan aturan yang berlaku secara prosedural.

Demikian halnya dari segi penggajian, insentif servis, dan insentif lainnya juga berdasarkan pada aturan berlaku. Bagi karyawan fomula tidak diberikan insetif selama masa training tiga bulan. Setelah lepas dari masa itu, barulah mereka diberikan sama halnya dengan karyawan yang telah lepas masa training.

Bentuk-bentuk implementasi yang diterapkan pimpinan kepada bawahannya merupakan wujud dari tongeng yaitu kepatutan pada aturan. Dalam hal ini, nilai yang dikedepankan oleh pimpinan sejalan dalam konteks kearifan lokal. Menurut To MaccaE ri Luwu bahwa tongeng dianggap sebagai ade' puaraonro atau aturan berkekuatan tetap (Tenrigau, 2017) yang harus dipatuhi dan dijalankan karena merupakan konsensus bersama.

Dalam memimpin sebuah perusahaan tidak pernah lepas dari nilai kepemimpinan secara umum, dimana mengedepankan kepentingan organisasi diatas kepentingan pribadi, memotivasi karyawan, menjadi contoh teladan dan lain-lain. Nilai-nilai yang diterapkan pada BM Residance Hotel Palopo pada dasarnya juga merupakan nilai-nilai yang dianut masyarakat luwu yaitu nilai budaya lokal yang dijadikan prinsip dalam memimpin perusahaan. Pemimpin harus mempunyai prinsip yang mengedepankan kebenaran, sehingga apabila ia berkata, maka kata-katanya adalah benar dan selalu terkait dengan hati yang bersih.

Wujud lain dari tongeng dalam gaya kepemimpinan BM Residence Hotel dapat dilihat pada tutur kata yang benar dan transparan terhadap karyawan-karyawan BM Residence Hotel. Jadi untuk mencapai tujuan perusahaan, maka tongeng menjadi nilai yang dikedepankan dan 
sekaligus memberikan contoh teladan kepada karyawan-karyawannya. Jadi nilai tongeng (kebenaran) yang dianut oleh aktor (pemimpin) tidak terlepas dari kebijakan, prosedur, dan aturan yang berlaku serta mempertanggung-jawabkan.

Memimpin sebuah perusahaan memang gampang-gampang susah. Bagi seorang pimpinan, berkata benar merupakan prinsip dalam menjalankan perusahaan dan pada umumnya manusia memang dituntut peduli terhadap nilai kebenaran. Dari hasil yang di dapat dalam wawancara bersama pimpinan perusahaan menunjukkan bahwa dalam memimpin harus mengedepankan kebenaran karena kebenaran membuka pintu rejeki.

Dari pernyataan tersebut dapat diartikan bahwa aktor (pemimpin) memiliki prinsip tongeng untuk selalu berkata benar dan berbuat benar dalam segala urusan karena kebenaran akan membuka pintu rejeki. Atinya bahwa secara epistimologi (makna) nilai tongeng bagi pimpinan perusahaan tidak hanya diwujudkan dalam bentuk patuh pada aturan tetapi juga dimaknai sebagai sebuah rezeki.

Dalam kepemimpinan aktor (pemimpin) dengan menggali nilai tongeng dibuktikan juga dengan sikap seorang pemimpin yang melakukan transparansi pada para karyawannya. Aktor (pemimpin) percaya bahwa sikap transparansi kepada karyawan akan membuka sikap kepercayaan dan loyalitas karyawan kepada pimpinan BM Residence Hotel.

\section{Mewujudkan Lempu’ Melalui Tindakan Transparansi}

Leтри' adalah prinsip tindakan yang menekankan pada hal-hal yang jujur dan berupaya menghindari sesuatu yang tidak benar. Dalam artian bahwa jujur merupakan kewajiban yang dianut baik dalam kata-kata maupun tindakan atau dengan kata lain satunya kata dengan perbuatan.

Wujud nilai lempu' bagi aktor (pemimpin) BM Residence Hotel adalah selalu percaya dan bersikap jujur serta menjalankan tanggung jawab atau amanah yang telah diberikan. Konsep kejujuran ini menjadi syarat utama, karena hanya dengan kejujuran kita akan memiliki kemampuan moral. Kejujuran yang bermoral akan melahirkan sebuah kepercayaan kepada yang selama ini dipandang telah hilang oleh adanya krisis kepercayaan.

Berada di tengah-tengah kaum milenial sekarang ini telah banyak di temui para tetinggi serta para generasi muda yang telah mencoreng nilai kejujuran, Hal itu dibuktikan dengan maraknya aksi penipuan di berbagai aspek yang dapat merugikan pihak manapun. Sebagai seorang pemimpin di jaman sekarang ini memang terbilang sulit menegakkan kejujuran, tetapi sebagai pemimpin sudah menjadi tugas baginya untuk selalu memegang nilai kejujuran.

Nilai lempu' bagi aktor dianggap sangat berat untuk dilaksanakan. Hal tersebut karena terkait dengan kemampuan untuk berkata secara transparan sementara dalam dunia kerja, tidak semua hal-hal dapat diungkapkan secara detail. Artinya bahwa setiap perkataan dan tindakan harus sejalan dan tidak saling bertentangan. Hal sejalan dengan La Manasse To Akkarangeng/La Baso (Rahman, 2013) bahwa:

Naia riasennge malempu, massuke’ ri alenai. Naia riasennge makkeda tongeng tennassurie belle timunna. 
(Adapun yang disebut jujur, dirinya dijadikan ukuran. Adapun yang disebut berkata benar, tidak keluar perkataan bohong dari mulutnya).

Pandangan La Manasse To Akkarangeng/La Baso yang menekankan pada berkata benar yaitu tidak keluar perkataan bohong dari mulutnya dapat dimaknai sebagai unsur transparansi. Artinya bahwa kejujuran itu dimaknai sebagai transparan, yaitu satunya kata dengan perbuatan.

Salah satu bentuk mengedepankan nilai lempu' pada BM Residance Hotel Palopo adalah pemberian insentif service kepada karyawan setiap bulannya sebesar lima persen. Insentif service ini sudah disampaikan sebelumnya kepada karyawan. Jadi pemberian insentif service merupakan wujud nyata dari implementasi nilai lempu' karena apa yang diucapkan atau yang tertulis diimplementasikan secara nyata kepada karyawan.

Melaksanakan nilai lempu' di BM Residance Hotal Palopo memberikan manfaat yang besar. Transparan setidaknya memberikan kepercayaan sehingga perusahaan dapat melaksanakan operasional bisnisnya dari waktu ke waktu (going concern) atau umur/usia yang panjang.

Dalam hal ini, secara kearifan lokal, To Maccae ri Luwu dari percakapannya dengan La Manasse To Akkarangeng (La Baso), (Rahman, 2013) menyatakan bahwa:

Aga Lamperi Sunge', Nene?

(Apa yang Memperpanjang Umur, Nenek?)

Naia Lamperi Sunge', Lempue. Eppa Gau'na toma lempue. Seunai, risalaie na'dampeng. Maduanna, riparennuangie tennapajekkoi. Bettuanna risanresie tennapabell.eang. Matellunna temmangoainngi taniae anunna. Maeppana, tesesse' deceng rekko alena podecengngi.

(Adapun yang memperpanjang umur, ialah kejujuran. Empat jenisnya orang jujur. Pertama, orang yang bersalah padanya tapi ia maafkan. Kedua, dipercayai dan tidak mencurangi. Artinya ia dijadikan saudara dan tidak mengkhianati. Ketiga, tidak serakah terhadap apa yang bukan miliknya. Keempat, tidak mencari kebaikan jika hanya ia akan menikmatinya).

Jika dibawa dalam konteks kearifan lokal, umur panjang yang dimaksud di atas dapat bermakna going concern atau kontinuitas perusahaan. Artinya bahwa ketika pimpinan BM Residance Hotel Palopo menerapkan transparansi, maka kondisi perusaahaan akan semakin baik sehingga dapat memberikan dampak positif terhadap kontinuitas operasionalisasi perusahaan kini dan di masa yang akan datang.

Dalam pandangan To MaccaE ri Luwu (Darwis dan Dilo, 2012) bahwa didasarkan pada sifat "acca na lempu, warani na getting, mappasanre ri Puang SeuwaE," artinya pandai mempertimbangkan dan jujur, berani dan teguh pendirian, berserah kepada Tuhan Yang Maha Esa. Ungkapan ini menunjukkan bahwa esensi siri' hanya mungkin diperoleh seseorang yang pandai dan jujur, berani dan teguh, serta bertakwa kepada Tuhan Yang Maha Esa.

JEMMA, Volume 3 Nomor 1, Maret 2020 | 19 


\section{Getteng: Memimpin dengan Penuh Keteguhan Hati}

Getteng adalah perilaku atau sikap yang kuat untuk tetap berpegang teguh pada prinsip, tuntutan, pernyataan, atau tindakan yang benar-benar dipahami dan melekat dalam jiwa sanubari. Bagi seoerang pimpinan, memelihara atau mempertahankan posisi yang diyakini sebagai suatu kebenaran merupakan sesuatu yang mesti dilakukan. Hal ini yang selalu menjadi acuan bagi pimpinan BM Residance Hotel Palopo dalam menggambil tindakan.

Nilai-nilai dalam bentuk ketegasan (getteng) yang ditunjukkan Selvia Pasande sebagai pimpinan BM Residence Hotel Palopo pada dasarnya sejalan dengan yang dikemukakan To Ciung Maccae ri Luwu bahwa empat perbuatan nilai keteguhan hati, yaitu (a) tak mengingkari janji, (b) tak mengkhianati kesepakatan, (c) tak membatalkan keputusan, tak mengubah kesepakatan, dan (d) jika berbicara dan berbuat, tak berhenti sebelum rampung (Rahim,1985) dalam (Tenrigau, 2017).

Nilai getteng ini memiliki hubungan dengan nilai tongeng, jika tidak bisa memegang erat nilai tongeng maka tidak bisa pula menegakkan nilai getteng. Sehubungan dengan hal tersebut, maka dalam menegakkan nilai getteng (tegas), actor (pemimpin) berpatokan pada kebijakan, prosedur, dan peraturan yang berlaku (tongeng). Sifat seorang aktor (pemimpin) yang tongeng dan lempu', harus ada dan tetap percaya bahwa pemimpin harus menciptakan moral dan kemampuan untuk menciptakan kepercayaan. Nilai ketegasan harus selalu diterapkan dalam memimpin sebuah perusahaan agar apa yang dipimpinnya sesuai dengan apa yang menjadi tujuan perusahaan dan kebijakan yang berlaku dalam perusahaan.

Salah satu unsur yang dimaksud To Maccae ri Luwu (Rahman, 2013) di atas adalah keteguhan satunya kata dengan perbuatan sehingga jika bekerja harus tuntas atau rampung sebelum selesai. Artinya bahwa walaupun pada pembahasan di atas disebutkan bahwa satunya kata dengan perbuatan adalah perbuatan dari lempu' (kejujuran), tetapi teguh pada apa yang diucapkan dan dilakukan merupakan bentuk dari tongeng (ketegasan).

Pemimpin dalam BM Residence Hotel adalah contoh pemimpin yang baik, dimana pemimpin memiliki ciri seorang pemimpin demokratis, pemimpin yang bisa mensinkronisasikan kepentingan dan tujuan organisasi dengan kepentingan pribadi, selalu memotivasi bawahannya supaya sukses, mengutamakan kerja sama team work, senang menerima saran, pendapat dan kritik dari bawahannya dan rendah hati. Bukan seorang pemimpin otokrasi yang menganggap bawahan sebagai alat semata-mata dan tidak perlu dihargai, menjadi penguasa dan pemaksaan.

\section{Menjaga Keharmonisan Dalam Bekerja Wujud Nilai Adele'}

Secara harfiah adele' berarti adil atau keadilan yang merupakan perwujudan tingkah laku dari lidah, tingkah laku dari hati, dan tingkah laku dari perbuatan yang mesti diperhatikan oleh pihak-pihak dalam masyarakat. Seperti yang diutarakan Rahman (2013) konsep keadilan yang diaktualisasikan di dalam konsep kepemimpinan raja-raja Luwu sejak dahulu bersandar pada filosofi yang dikemukakan oleh I Sehe Makkunrai yaitu:

Siwennimi adele mapparenta datu-e padami patappulo wenni sempajangnge.

JEMMA, Volume 3 Nomor 1, Maret 2020 | 20 
(Pemerintah yang berbuat adil dalam semalam sama halnya empat puluh malam mendirikan sembahyang).

Dipertegasnya bahwa aro adele agaukeng de' na mappile pile na pappada ngasengngi tauwede

(Adele itu adalah perilaku yang tidak memilih-milih atau membeda-bedakan dan menyamaratakan semua orang).

Dari konsep adele' (adil) di atas, berdasarkan pada filosofi Kerajaan Luwu bahwa adele' (Adil) dapat diartikan sebagai sebuah tindakan atau perilaku yang tidak berat sebelah, tidak memihak, berpihak kepada kebenaran, dan bertindak sepatutnya atau tidak sewenang-wenang.

Ungkapan dari salah satu karyawan menunjukkan bahwa dalam kepemimpinan yang dijalankan aktor (pemimpin) memang masih belum bisa dikatakan bahwa pemimpin menjalankan kepemimpinannya sesuai dengan nilai adele'. Secara logis memang tidak ada manusia yang dapat bersikap adil, tetapi nilai adele' ini merupakan nilai yang sangat penting untuk di pahami oleh setiap pemimpin secara luas dan dapat menjadi sandaran atau landasan dalam menjalankan amanah dan tanggung jawab, terkhusus di BM Residence Hotel.

Salah satu wujud adele' yang dilakukan oleh aktor adalah menciptakan harmonisasi dalam suasana kerja. Harmonisasi yang dimaksud aktor adalah menciptakan rasa kebersamaan sesama karyawan dan pimpinan supaya tidak ada di antara mereka yang merasa dipinggrikan atau dianaktirikan karena menganggap merasa tidak mendapatkan rasa adil dari pimpinan. Olehnya itu, dengan menciptakan harmonisasi di antara karyawan dan pimpinan, maka mereka meresa satu rasa satu nasib atau merasa diperlakukan dengan adil.

\section{Sipakatau (Saling Menghormati)}

Sipakatau adalah inti dari atau pangkalan sikap, keterbukaan yang berarti saling membuka diri dalam peran-peran hidup kemanusiaan. Dari sikap sipakatau inilah akan menjalin interaksi sosial dalam masyarakat yang sesuai dengan nilai-nilai ideal budaya Bugis-Makassar (Mattulada. 1989: 4) dalam (Rahman, 2013).

Sipakatau merupakan bentuk saling menghargai, saling menghormati, saling mempercayai dan saling memanusiakan juga mengandung makna rasa solidaritas atau kebersamaan yang kuat dan dapat menerima orang lain apa adanya dalam kehidupan bermasyarakat. Nilai sipakatau merupakan unsur yang dijabarkan dari nilai siri' na pacce yang mengandung rasa kebersamaan dan solidaritas antar sesama manusia.

Pemimpin merasa bangga bisa menciptakan lingkungan kerja yang harmonis, tidak ada tembok yang memisahkan antara pemimpin dan para karyawannya. Seluruh perbedaan sosial tercairkan, tak ada perbedaan antara kaya dan miskin, pimpinan dan bawahan, turunan bangsawan dan rakyat biasa, dan sebagainya, yang dinilai atas diri seseorang adalah kepribadiannya yang dilandasi sikap budaya sipakatau.

Secara psikologi setiap manusia ingin dipandang sebagaimana esensi dan eksistensi penciptaanya. Maksudnya bahwa dalam kehidupan sosial kita selayaknya memandang manusia seperti manusia seutuhnya dalam kondisi apapun. Dalam pribahasa bugis yaitu teppettu

JEMMA, Volume 3 Nomor 1, Maret 2020 | 21 
maoompennge', Teppolo massellomoe', yang mengandung makna peringatan agar bijaksana menghadapi suatu permasalahan. Toleransi dan tenggang rasa perlu dipupuk supaya keinginan tercapai tanpa kekerasan. Pada intinya kita seharusnya saling menghormati sesama manusia tanpa melihat dia miskin atau kaya atau dalam keadaan apapun.

\section{SIMPULAN DAN SARAN}

\section{Simpulan}

Berdasarkan hasil pembahasan analisis data pada pemasalahan yang diangkat mengenai mengungkap nilai-nilai siri' na pesse gaya kepemimpinan pada BM Residence Hotel di Kota Palopo, maka kesimpulan dari penelitian ini adalah :

1. Wujud nilai tongeng pada kepemimpinan BM Residence Hotel adalah patuh pada aturan yang berlaku dan mampu mempertanggungjawakannya. Atas dasar tanggung jawab dalam memimpin dapat memotivasi dan memberikan contoh teladan untuk karyawannya bagaimana cara memimpin yang bertanggung jawab dan memiliki nilai kebenaran.

2. Wujud nilai lempu' pada kepemimpinan BM Residence Hotel yaitu memiliki sifat jujur yaitu apa yang dikatakan atau disepakati seyogyanya dilaksanakan dalam bentuk tindakan.

3. Wujud nilai getteng pada kepemimpinan BM Residence Hotel yaitu tegas dengan penuh keteguhan hati. Ketegasan ini berupa keteguhan hati yang kuat dalam menerapkan apa yang telah disepakati baik lisan maupun tertulis.

4. Wujud adele' pada kepemimpinan BM Residence Hotel tidak membedakan antara sesama karyawan dan menciptakan harmonisasi dalam perusahaan. Harmonisasi adalah bentuk perlakukan pimpinan kepada bawahannya yang memperlakukan sama sehingga dengan demikian bawahan merasa diperlakukan sama.

5. Wujud nilai sipakatau pada kepemimpinan BM Residence Hotel adalah saling menghargai dan menghormati sesama karyawan dan pimpinan. Secara psikologi setiap manusia ingin dipandang sebagaimana esensi dan eksistensi penciptaanya. Maksudnya bahwa dalam kehidupan sosial kita selayaknya memandang manusia seperti manusia seutuhnya dalam kondisi apapun. Dalam pribahasa bugis yaitu teppettu maoompennge, Teppolo massellomoe, yang mengandung makna peringatan agar bijaksana menghadapi suatu permasalahan. Toleransi dan tenggang rasa perlu dipupuk supaya keinginan tercapai tanpa kekerasan. Pada intinya kita seharusnya saling menghormati sesama manusia tanpa melihat dia miskin atau kaya atau dalam keadaan apapun.

\section{Saran}

Adapun saran sebagai kelanjutan dari kesimpulan diatas yang dimaksudkan untuk menjaga eksistensi nilai-nilai lokal dalam gaya kepemimpinan BM Residence Hotel, yaitu:

1. Menumbuhkan kesadaran akan pentingnya nilai-nilai lokal terutama kepada para generasi muda sebagai calon pemimpin masa depan.

2. Kepemimpinan dengan nilai-nilai keluhuran atau nilai-nilai siri' na pesse tetap dipegang erat untuk membangun ketertiban, keharmonisan, dan keamanan kehidupan sosial. 
3. Memasukkan muatan materi tentang kearifan lokal untuk membangun pemahaman tentang nilai-nilai lokal, dalam kegiatan-kegiatan pelatihan kepemimpinan sehingga dapat terwujud dalam bentuk aktualisasi dalam kepemimpin BM Residence Hotel.

\section{DAFTAR PUSTAKA}

Baihaqi, Muhammad Fauzan. 2010. Pengaruh Gaya Kepemimpinan Terhadap Kepuasan Kerja dan Kinerja dengan Komitmen Organisasi Sebagai Variabel Intervening (Studi Pada Pt. Yudhistira Ghalia Indonesia Area Yogyakarta). Skripsi Manajemen, Fakultas Ekonomi Universitas Diponegoro Semarang.

Darwis, Rizal dan Dilo, Usman, Asna. 2012. Implikasi Filsafah Siri' Na Pesse pada Masyarakat Suku Makassar di Kabupaten Gowa. Jurnal el Harakah. Vol.14 No.2: 186-205.

Fahmi, Irham. 2017. Manajemen Kepemimpinan Teori \& Aplikasi (cetakan ke-4). Bandung: Alfabeta.

Mariam, Rani. 2009. Pengaruh Gaya Kepemimpinan dan Budaya Organisasi Terhadap Kinerja Karyawan Melalui Kepuasan Kerja Karyawan Sebagai Variabel Intervening Studi Pada Kantor Pusat Pt.Asuransi Jasa Indonesia (Persero). Skripsi Manajemen, Fakultas Ekonomi Universitas Diponegoro Semarang.

Mattingaragau T, Andi. 2015. Model Penganggaran Berbasis Spiritualitas Siri' Na Pesse dalam Upaya Mewujudkan Aparatur Sipil Negara yang Berakuntabilitas. Jurnal "Administrasi Publik". Volume XI Nomor 1: 25-32.

Novarima, Aji, Tsani, dkk. 2018. Mengungkap Praktik Senjangan Anggaran Pada Organisasi Nirlaba: Badan Pengelola Dana Amanat (Studi Etnometodologi). Jurnal Akuntansi Aktual. Vol. 5, No. 1: 63-75

Nurwanah, Andi dan Hanafie, Hadriana. 2018. Memaknai Creative Accounting Dengan Keindahan Nilai-Nilai Kearifan Lokal Siri' Na Pacce. Jurnal ASSETS. Volume 8, Nomor 1: $167-182$

Putra, Utama, Gede Prawira dan Subudi, Made. 2012. Pengaruh Disiplin Kerja, Gaya Kepemimpinan, dan Motivasi Kerja Terhadap Kinerja Karyawan Pada Hotel Matahari Terbit Bali Tanjung Benoa-Nusa Dua.

Rahman, Rezki, Fahri. 2013. Aktualisasi Nilai Budaya Lokal Dalam 'r remimpinan Pemerintahan Di Kota Palopo. Skripsi Ilmu Pemerintahan, Fakultas Ilmu Susial dan Ilmu Politik Universitas Sultan Hasanuddin Makassar

Rustan, Edhy. 2010. Budaya Leluhur Dalam Memperkukuh Tatanan Masyarakat Di Era Globalisasi. Universitas PGRI Adibuana Surabaya: Balai Bahasa Surabaya

Ruvendi, Ramlan. 2005. Imbalan dan Gaya Kepemimpinan Pengaruhnya Terhadap Kepuasan Kerja Karyawan Di Balai Besar Industri Hasil Pertanian Bogor. Jurnal Ilmiah Binaniaga. Vol. 01 No.1: 17-26.

Tenrigau, A Mattingaragau dan Damayanti, R.A. 2015. Menggali Nilai-Nilai Pesse Na Siri' dalam Penyusunan Anggaran: Studi Etnografi di Pemerintah Kabupaten Luwu Timur. 
Tenrigau, Andi Mattingaragau, Mattayang, Besse, Wahida, dan Rahim, Ratna. 2018. Keluwuan (cetakan pertama). Palopo: Andi Djemma Press

Tenrigau. 2017. Menemukenali Konsep Penganggaran Siri' Na Pesse: Studi Kasus Berbasis Kearifan Lokal di Kabupaten Luwu Timur (Exploring Of Siri' Na Pesse Budgetary Concept: a Case Study Of Local Wisdom In Luwu Timur Regenc). Program Doktor Ilmu Ekonomi, Fakultas Ekonomi Dan Bisnis Universitas Hasanuddin Makassar

JEMMA, Volume 3 Nomor 1, Maret $2020 \mid 24$ 